\title{
Strategic of land resources management supporting agribusiness development in Aceh Province
}

\author{
Eka Fitria*, Rachman Jaya, Cut Hilda Rahmi, and Husaini \\ Aceh Assessment Institute Agriculture (BPTP) Aceh, 23125, Indonesia
}

\begin{abstract}
The objectives of this study were to obtain a strategy of the land resources management to support the development of agribusiness and to arrange a reliable policy to be implemented. The system approach was used, 4 experts were involved with background researchers, academicians and practitioners. Synthesized of the data using are Strength, Weakness, Opportunity, Threats (SWOT) and Analytical Hierarchy Process (AHP) techniques. The result of the study shows that based on the alternatives of the internal factors strategy is discusses increasing the sustainable land management, empowerment of community program through the development of eco-tourism village, implementing the Information Technology 4.0 and increasing the millennial-farmers capacity. An external factor involves determining the land agriculture-sustainable and improving the water management. Based on policy options by the strength: design a development village by primary commodity with weight 0.246 , weakness: increasing the urbanization (0.226), opportunity: increasing the food demand (0.434) and from threats: agriculture productive land conversion trend (0.256). The implications managerial offered to agricultural stakeholder in Aceh Province for decreasing the urbanization through improvement the farmer's capacity, especially on millennial farmers to response the increasing of food demand with efforts of decrease the agriculture-land conversion by optimization land-use and improvement crop-index.
\end{abstract}

\section{Introduction}

From the sustainability perspective, the agricultural development that more focuses on economic growth will harm sustainable land resources. To keep the sustainable agricultural development needed a special effort to manage land resources based on the strategy and policy implemented. The agricultural development that consideration land resources are one of the ways to increase social welfare, especially the farmers, indeed sustainable agricultural development more has an impact on farmers welfare if synergized with the development of the agribusiness system [1]. According to Nugroho, [2] the existing land management is related to the provision of national food, so the land management is not under the

\footnotetext{
* Corresponding author: ekafitriabptpaceh@gmail.com
} 
sustainability land approach will have an impact on land productivity decrease and finally to become barren land.

Naginggolan [1] stated that the sustainability of agricultural development can be undertaken with agribusiness system development, this stated caused it was implemented through centered, efficient, integrated as well as have the responsibility to keep the environmental sustainability. The agribusiness system is an activity that is related to agricultural business (plant and animal) as raw material based on market-oriented and valueadded. The development of its will has an impact on the actors of agribusiness through increasing the incomes and value-added for availability the employment.

To develop the agribusiness system for agricultural land management should be a formulated strategy that is based on the strength, weakness, opportunity and threat aspects as well as the options of the policy implications that synergised with sub-system on upstream to downstream of agribusiness based on the strategy of land resources management. The purposes of this study were to obtain a strategy of land resources management to support the agribusiness development and the implication of the policy options will be undertaken.

\section{Methods}

The approach was implemented in this research the system approach caused complexity problems, so the multi-disciplinary recommended to use. The research study is referred to as non-probability sampling or purposive, the numbers of key-informants (experts) involve of 4 who has a background as researchers, academicians and practitioners in agricultural development, especially inland resources management. The qualifications of expert are minimally $\mathrm{PhD}$ degree and have experienced 10 years in agricultural development management for the researcher, likewise for academicians, meanwhile for practitioners minimally have experienced 20 years in agricultural development management and B.Sc degree. All experts are still involved in agricultural decision policy, so in line with the boundary of the research.

The collecting of the data was done by an in-dept interview with the experts. In the interview process is used structured questioners for SWOT and AHP techniques. The SWOT analysis (Strength, Weakness, Opportunity, Threat)is implemented to identify systematic several factors for formulation the strategy will be implemented [3], meanwhile to determine the decision policy options is used the multi-criteria decision support techniques, namely the Analytical Hierarchy Process (AHP) which was developed by [4].

The first step in the AHP technique is designing the structure of hierarchy (fig. 1) and the analyzing the expert's judgment based on a pairwise comparison approach. The geometric average is used the calculated average of expert judgments. The research was done by Januari - Oktober 2019, through 2-3 times round-table. Verification of the strategy is implemented to assess the suitability of the strategies before being to offered for agricultural stakeholders in Aceh Province. The process of the verification is based on the face-validity technique. As complete stages of the research can be seen in figure 2 . 


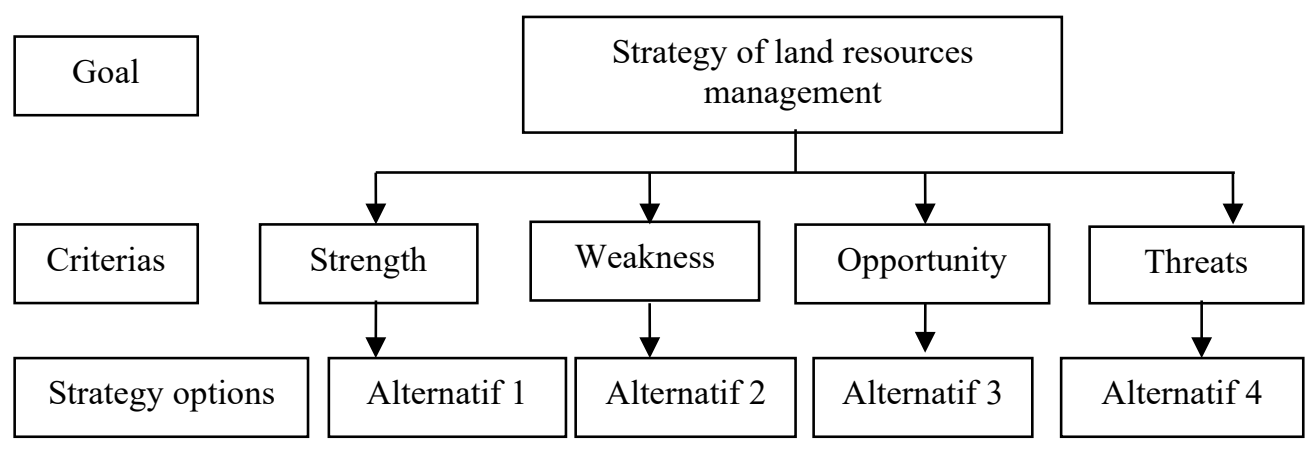

Fig. 1. A design of Hierarchy structure

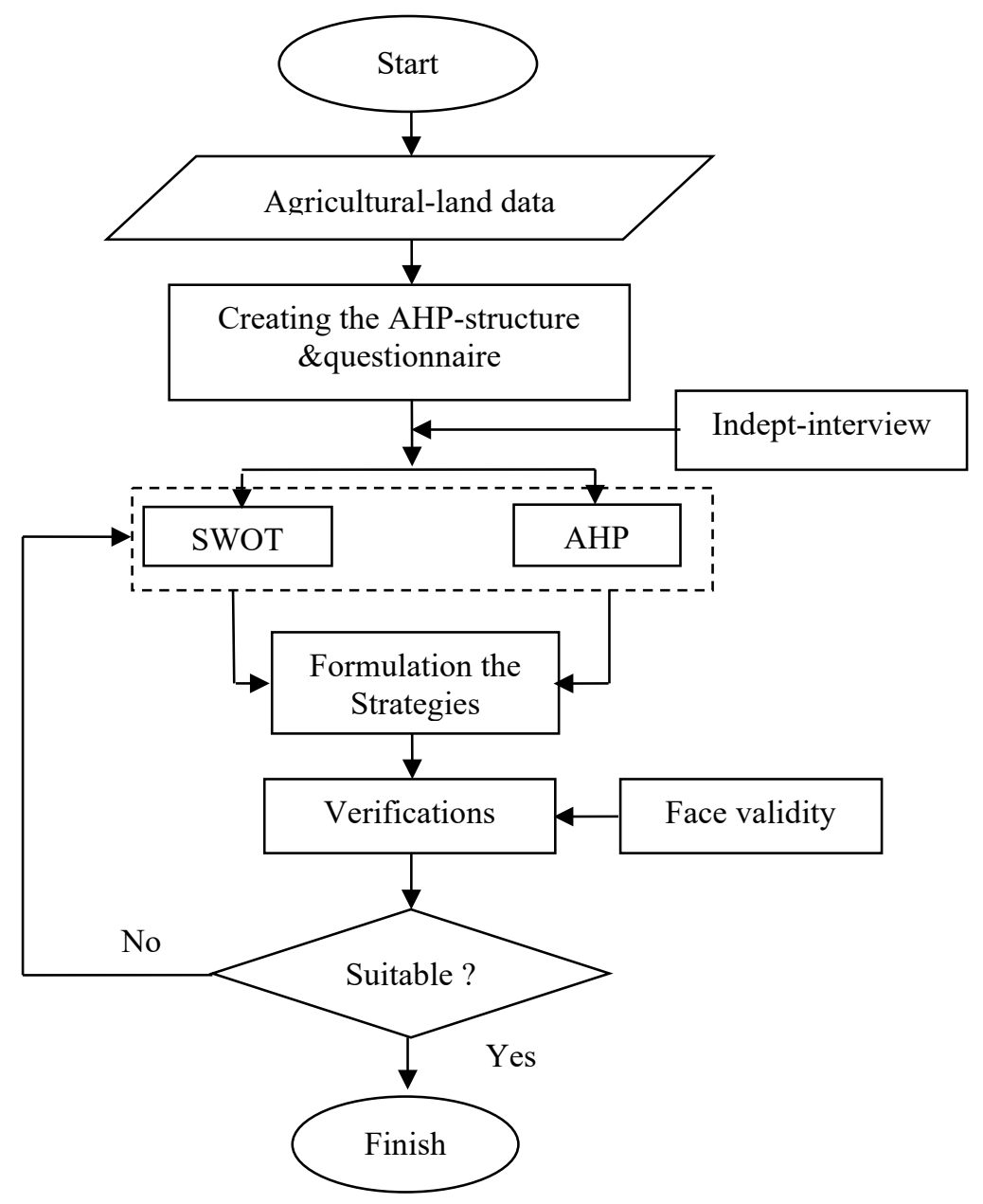

Fig. 2. The flow-chart of the study 


\section{Result and discussion}

\subsection{Determining of the option strategy for agricultural land-management}

In this research, the main focus was determining strategy options that can be implemented by local stakeholders (Figure 3). The strategy is created by synthesized an expert's judgment that expresses through the SWOT matrix (internal-external factors). According to Oduniyi and Tekana [5] one of the key success factor on land resources management is availability and best practices of the agriculture water system as well as farm-based local characteristic.

The strategies was formulated by SWOT technique. The outputs of AHP technique can be seen on table 1. Based on table 1, showed that from strength aspect the alternative strategy with highly weight importance is development the village's zone by primary commodity (0.246), and seconds as developing villages has competitiveness (0.245). Generally, the purpose of development of village's zone was to upgrade social welfare. To reachit has to implement agricultural activities based on primary commodity for each location development. Approach that can be applied is the agribusiness system due to this activities technicaly is given positive impact for agricultural actors. Jaya et al. [6] stated that in the agricultural development is depend on strategy dynamic environment. The concepts of sustainable agricultural development basicly is agricultural development through optimize management on all resources i.e material resources such as land availability and human resources (demographic bonus) that implemented by institutions agricultural [7].

\begin{tabular}{|c|c|c|}
\hline External factors & $\begin{array}{l}\text { Strength (S): } \\
\text { - Land-use innovation technologies } \\
\text { - Sustainable land management } \\
\text { - Agricultural infrastructure } \\
\text { - There are development villages } \\
\text { program based on primary } \\
\text { commodities }\end{array}$ & $\begin{array}{l}\text { Weakness (W): } \\
\text { - Agriculture system still } \\
\text { conventional } \\
\text { - Deareasing of national paddy field } \\
\text { - Interest of youth to become } \\
\text { farmers still low } \\
\text { - Urbanization level increasing } \\
\text { - Lack of farm-capital } \\
\text { - Agriculture water management } \\
\text { still conventional }\end{array}$ \\
\hline $\begin{array}{l}\text { Opportunity (O) } \\
\text { - Improvement of IT } \\
\text { - Increasing of food demand } \\
\text { - There are empowerment } \\
\text { community program } \\
\text { - Increasing eco-tourism based } \\
\text { on Islamic perspective } \\
\text { (syariah) }\end{array}$ & $\begin{array}{l}\text { Strategies SO: } \\
\text { 1. Implementation of sustainable } \\
\text { land-management } \\
\text { 2. Implementation of } \\
\quad \text { empowerment community } \\
\text { program based on eco-tourism }\end{array}$ & $\begin{array}{l}\text { Strategies WO: } \\
\text { 1. Implementation of agricultural } \\
\quad \text { system based on IT } 4.0 \\
\text { 2. Increasing of youth capacity to } \\
\text { become millenial farmers }\end{array}$ \\
\hline $\begin{array}{l}\text { Threat (T) } \\
\text { - Decreasing of land carrying } \\
\text { capacity } \\
\text { - Global warming } \\
\text { - Increasing trend of agriculture } \\
\text { land conversion } \\
\text { - Complexity of the supply chain } \\
\text { - Lack of water supply } \\
\text { - Productivity of dry land still } \\
\text { low }\end{array}$ & $\begin{array}{l}\text { Strategies ST: } \\
\text { 1. Making a new paddy field } \\
\text { 2. Optimization of land-use } \\
\text { throughincreasing of plant- } \\
\text { index }\end{array}$ & $\begin{array}{l}\text { Strategies WT: } \\
\text { 1. Deteriming of sustainable paddy } \\
\text { field by legal constitution } \\
\text { (Qanun) } \\
\text { 2. Improvement of agriculture } \\
\text { water management }\end{array}$ \\
\hline
\end{tabular}

Fig. 3. SWOT matrix (internal-external factors) 


\subsection{Determining of weight importance internal aspect}

The purpose of this stage was to determine weight importance for each the alternative. Based on exsisting conditions, there are program that has purpose to reach sustainable land management by local government. Conceptualy, the strategy of land management isa design that optimilization all activities can be done to achieve sustainability land management, including to protect land agriculture from damage and conversition to another use except agricultural activity, likewise to reach national food security by keep agriculture water resources through improvement land and water institutions [8].

Table 1. The weight importance for each alternatives strategy for land management

\begin{tabular}{|c|l|c|c|}
\hline & \multicolumn{1}{|c|}{ Alternative strategies } & $\begin{array}{c}\text { weight } \\
\text { importance }\end{array}$ & $\begin{array}{c}\text { Priority } \\
\text { scale }\end{array}$ \\
\hline Strength (S) & $\begin{array}{l}\text { Development the village's zone by primary } \\
\text { commodity }\end{array}$ & 0,246 & 1 \\
\hline & Developing villages has competitiveness & 0,245 & 2 \\
\hline & $\begin{array}{l}\text { There are the programs of sustainable land } \\
\text { management by local government }\end{array}$ & 0,220 & 3 \\
\hline Weakness (W) & Urbanization level still increase & 0,226 & 1 \\
\hline & Lack of agriculture water management & 0,281 & 2 \\
\hline & Lack of farm-capital & 0,211 & 3 \\
\hline Opportunity O) & Increasing of food demand & 0,434 & 1 \\
\hline & $\begin{array}{l}\text { There are empowerment community program } \\
\text { by local government }\end{array}$ & 0,349 & 2 \\
\hline & Increasing implemented of IT 4.0 & 0,108 & 3 \\
\hline Threat (T) & Increasing of agricultural land conversation & 0,256 & 1 \\
\hline & Productivity of dry land still low & 0,198 & 2 \\
\hline & Global warming & 0,169 & 3 \\
\hline
\end{tabular}

As the weakness aspects, the most influencing factor on sustainability land-management is the increasing trend of urbanization (0.226) and lack of agricultural water-management (0.218) as well as lack of farm-capital avaiability (0.211). Mansur [9] stated that one of the urbanization factors is dwindling agriculture-land due to increase the land agriculture productive to non-agricultural activities [10]. On the other hand, the negative impact of urbanization for village areas is the reduction of productive agricultural-worker, so when planting and harvesting season in that location there is a shortage of agricultural-worker. For instance, the economic growth of Banda Aceh is higher than Aceh Besar district, where the gross domestic product (GDP) indicator Banda Aceh IDR 54.70 million/years, meanwhile PDRB Aceh Besar district only IDR 26.4 million/years. This fact will be the main influencing the urbanization occurred [11]. On the other side, Indonesia country is a tropical zone. Based on climate typical have rain-fall is an agricultural water resource, but accoording to Sutrisno and Adang [12] the utilized it's still not optimal. One of the reasons is the lack of water management, there are innovative technologies can be implemented such as pond and dam technology to harvest rain-fall as well as implementation the agriculture precision using IT 4.0.

\subsection{Determining of weight importance external aspect}

As the AHP analyzed on opportunity aspect is founded that increasing the food demand (0.434) as main factors in sustainable land-management and then empowerment by the community (0.349) as well as there is a trend of IT 4.0 uses. Increasing the food demand is related to raising the number of people. On the other side, nowadays there is decreasing in 
the national paddy field that can be influenced food production. According to Wahyunto [13], several challenges that must be faced by the national or local government are there is increasing of the food demand and the same times agricultural land conversion is increase as well as hard to reach the food diversification. Besides focused on the commodity, the critical aspects must be concern by local government is community development especially in agricultural villages which generally more poverty compared with urban zone [14]. The activities can be implemented such as knowledge to utilize local resources based on innovation technology in on-farm or off-farm. For example, Trisnawati et al. [15] suggestion that to create eco-tourism in the rural area. The urban is needed excursion that presenting the beauty nature-based on agriculture and hospitality of the rural community.

From a rural development perspective, one of the majority aspects is the implementation of IT 4.0. That is related to agricultural typical such as perishable products, so according to Yuantari et al. [16] the marketing dimension is critical to fulfilling consumer requirements (quality, quantity and time delivery). According to Sukur and Soesanto [17] nowadays, the smartphone has been using widely, including by farmers. This fact showed that the rural development is reliable to bedone in the rural zone.

By the threat dimension can be discussed that the agricultural land conversion $(0.256)$ as the main problem in sustainable land management. Then, low productivity of dryland $(0.198)$ as well as global warming aspect (0.169). The availability of land agriculture is one main factor to reach national or local food security. But reaching it has been hampered by there is agricultural land conversion, the majority to build infrastructure non-agriculture which more highly from making the new paddy field $[18,19]$. Winoto [20] stated that several factors that conversion of agricultural land such as 1 . increasing of rural people based on productive paddy field compared rural based on dryland, 2. the paddy field location very close with urban zone, 3. inequality infrastructure development between rural based on productive paddy field compared dryland. Meanwhile Akmal et al. [21] judgments that an agriculture land conversion is also influenced by human factors need to changes the quality of life. By dryland potency, in Aceh Province there are about 200.000 hectares, but the productivity of it still low, but according to Rengganis [22], the dry can be used to produce food such as paddy or corn commodity through implementation innovation technologies like selection variety for dryland and water management.

\section{Conclusion and recommendation}

The alternatives stratégies can be implemented by agricultural stakeholders in Aceh Province such as :

1. Based on internal aspects involves implementing sustainable land management, empowerment rural community, applying IT 4.0 in an agriculture production system, increasing the youth generation to become the farmers.

2. Based on external aspects involves increasing the paddy field through making the new paddy field, optimization land agriculture by increasing the plant-index, improving the agriculture water management.

3. Based on policy options can be implemented such as developing rural based on selection of primary commodities (strength), to handle the urbanization (weakness), there is increasing food demand (opportunity) and decreasing the agriculture land conversion.

\section{References}

1. Nainggolan, H.L., Johndikson, A, Development of agribusiness systems in the context of sustainable agricultural development, in Proceedings of the National Congress on 
Presision agriculture toward sustainable agriculture, 3 April 2012, Medan, Indonesia (2012)

2. Nugroho, S, P., J. Teknologi Lingkungan. 1, 1 (2000)

3. Rangkuti, F., Analisis SWOT Teknik Membedah Kasus Bisnis (Gramedia Pustaka Utama, Jakarta, 2017)

4. Saaty, T.L., The Analytic Hierarchy Process (New York: McGraw-Hill, 1980)

5. Oduniyi, O.S, Tekana, SS. Land. 10, 508 (2021)

6. Jaya, R., Lamhot, E.P., Muhammad, I., J. Pengkaj. Pengemb. Teknologi Pertan. 23, 3 (2020).

7. Susilowati, S, H. Forum Penelit. Agro. Ekon. 34, 1 (2016).

8. Pranadji, T. J. Analisis Kebijak. Pertan. 3, 3 (2005).

9. Mansur, J. Al-Munzir. 7, 1 (2014)

10. Eryani, I, G,A,P., J. Paduraksa. 3, 1 (2014)

11. SimahA., Abd. Jamal., J. Ilm. Mhs. 2, 3 (2017)

12. Sutrisno, N., Adang, H., J. Sumberd. Lahan. 13, 2 (2019)

13. Wahyunto, J. Inf. Pertan. 18, 2 (2009)

14. Mustangin, Desy, K., Nufa, P.I., Baruna S., Eni, P., J. Sosioglobal. 2, 1 (2017)

15. Trisnawati, A,E., Hari, W., Cipto, W., J. Pendidik. 3, 1 (2018)

16. Yuantari, MG,S., Arif, K., Ngatindriatun, J. Techno. 15, 1 (2016)

17. Sukur, M., Soesanto, J. Teknol. Inf. Dinamik. 19, 2 (2014)

18. Directorate of Food and Agriculture, Evaluation of the implementation of sustainable food agricultural land policy (National development planning agency, 2015)

19. Priyono, The conversion of agricultural land is a necessity or a challenge, in Proceedings of the National congress on Agricultural cultivation: Urgency and Strategy. Control of Changes in the Function of Agricultural Land, UNIB, 7 Juli 2011, Bengkulu, Indonesia (2011)

20. Winoto, J., Policy and control of agricultural land conversion and its implementation, in Proceedings of the National congress Handling Land Conversion and Achievement of Perpetual Agricultural Land. Coordinating Ministry for Economic Affairs and Center for Agricultural and Rural Development Studies, IPB, 13 December 2005, Jakarta (2005)

21. Akmal, C, Sugianto, Manfarizah, JIMFP. 1, 1 (2016)

22. Rengganis, H. J. Irigasi. 11, 2 (2016). 